\title{
The Next Great Global Knowledge Infrastructure Land Rush Has Begun
}

\author{
Will the USA or China Prevail?
}

Jane K. Winn and Yi-Shyuan Chiang

\author{
I INTRODUCTION: COULD CHINA PREVAIL AS ARCHITECT \\ OF THE EMERGING GLOBAL KNOWLEDGE INFRASTRUCTURE?
}

[China] should pursue innovation-driven development and intensify cooperation in frontier areas such as digital economy, artificial intelligence, nanotechnology and quantum computing, and advance the development of big data, cloud computing and smart cities so as to turn them into a digital silk road of the 21st century. ${ }^{1}$

[The USA] must continue to advance innovation that's ingrained with our approach to human rights, civil liberties and privacy. It is critically important in this age, when so many of our adversaries [such as the Chinese Communist Party] are twisting these technologies against American values. ${ }^{2}$

By 2020, there was no denying that the USA and China were engaged in a fullfledged trade war. A long, slow narrative arc that began with the rise of Japan, followed by South Korea, Taiwan, Hong Kong, Singapore and finally China as export-oriented economies with the support of the USA and other Western nations, appeared to be winding up for good. With the loss of this narrative, the likely future trajectory of global economic activity will become more difficult to predict. A nation's progress from economic backwardness through late development or catch-up industrialization strategies to middle-income or beyond could be mapped out relatively easily. The foundation of comparative advantage appears to be shifting from Industrial Revolution business strategies to business strategies emerging from the crucible of "digital transformation," but the winning formula for success in the new global information economy is not yet clear. The world trade system itself, so painstakingly assembled in the decades following World War II, appears to be

1 "President Xi Jinping's Speech at Opening of Belt and Road Forum" (Xinhua, 15 May 2017), https:// perma.cc/E6V5-YFHR.

= Brooke Singman, "US Technology Chief Warns China 'Twisting' Artificial Intelligence to Target Critics, as America Joins Global Pact" (Fox News, 28 May 2020), https://perma.cc/YP22-YYA6. 
unraveling, making it even harder for individual nations or enterprises to pinpoint future sources of global competitive advantage with any certainty.

Where some commentators might have seen an "Information Revolution" following the Industrial Revolution, others now believe they can discern a "Knowledge Revolution" gaining momentum. In 2003, the neoliberal international relations theorist Joseph Nye observed, "The current information revolution is based on rapid technological advances in computers, communications, and software that in turn have led to dramatic decreases in the cost of processing and transmitting information."3 A few years earlier, however, the so-called Father of Post-War Management Thinking4 Peter Drucker suggested the transformation was more radical than that:

What we call the Information Revolution is actually a Knowledge Revolution. What has made it possible to routinize processes is not machinery; the computer is only the trigger. Software is the reorganization of traditional work, based on centuries of experience, through the application of knowledge and especially of systematic, logical analysis. The key is not electronics; it is cognitive science. This means that the key to maintaining leadership in the economy and the technology that are about to emerge is likely to be the social position of knowledge professionals and social acceptance of their values. ${ }^{5}$

Technological advances including advances in data science, artificial intelligence (AI), machine learning, cloud computing, the Internet of Things, mobile computing and social production are all fueling this Knowledge Revolution. The consulting firm Gartner has grouped these advances together and labeled the bundle a "nexus of forces" that is transforming the "infrastructure of civilization." 6 While the economic rivalry between the USA and China is intensifying across many industries, it may be most intense in the struggle for control over the emerging global information architecture emerging out of this "Knowledge Revolution."

In order to distinguish a Knowledge Revolution from an Information Revolution, it is first necessary to distinguish knowledge from information. Data is generally thought of as records of simple factual observations, while information is data that has been organized and combined within structures to create meaning, with knowledge arising when meaningful information is contextualized in a form that can be used to solve problems. Knowledge viewed from this perspective may be thought of as the "strategic competence" of being able to discern "what one needs to know and

3 JS Nye, The Paradox of American Power: Why the World's Only Superpower Can't Go It Alone (New York, Oxford University Press, 2003), at 42.

4 "Peter Drucker," https://perma.cc/CT9X-9FQK.

5 Peter Drucker, "Beyond the Information Revolution," The Atlantic (1999), https://perma.cc/P4WX${ }_{4} \mathrm{X}_{2} \mathrm{~N}$.

6 C Howard, "The Nexus of Forces Is Creating the Digital Business" (2014), https://perma.cc/Z5B9$\mathrm{EP}_{2} \mathrm{~K}$; J Lopez, "Digital Business Success Depends on Civilization Infrastructure: A Gartner Trend Report” (2017), https://perma.cc/E3L2-DVMZ. 
remember what one ought to remember" through the application of a sense-making framework. ${ }^{7}$

On the question of whether a Western nation such as the USA or a non-Western rival such as the China would most likely prevail in the contest to lead the Knowledge Revolution now unfolding, the conventional wisdom among most Western observers seems to be that the odds are stacked in favor of the West. Western nations can claim to be the source of the Enlightenment's Scientific Revolution as well as liberal institutions such as free markets, representative democracy and the rule of law. Far from being perceived as a hotbed of innovation and entrepreneurship with the capacity to rival the USA in the production of knowledge, China is frequently viewed in the West as "totalitarian," which is the antithesis of a liberal society. In 2020, a conservative American think-tank asked, "Is China Totalitarian?" and answered in the affirmative:

By any reasonable measure, the PRC [People's Republic of China] is becoming a totalitarian state whose actions are dictated and determined by Xi Jinping and the Communist Party he heads .... To say otherwise is to ignore the totalitarian behavior of Communist China for the past four decades and to doubt that a despot like $\mathrm{Xi}$ will do whatever is necessary to maintain his power and control. ${ }^{8}$

In its World Report 2020, Human Rights Watch reached a similar conclusion. ${ }^{9}$ Even more neutral commentators feel justified in making oblique references to China's totalitarian character:

Great struggles between great powers tend to have a tipping point. It's the moment when the irreconcilability of differences becomes obvious to nearly everyone ... the curtailment of freedom that awaits Hong Kong is nothing like the totalitarian tyranny that Joseph Stalin imposed on Warsaw, Budapest and other cities. But the analogies aren't inapt, either. ${ }^{10}$

Given that authoritarianism generally refers to the harsh rule of a strong state that is not accountable to its citizens while totalitarianism generally refers to the use of political terror and an all-embracing ideology to politicize all aspects of life and subordinate all citizens to the state, ${ }^{11}$ China's critics might more accurately characterize it as authoritarian rather than totalitarian.

7 P Porrini and WH Starbuck, “Organizational Information and Knowledge," in JD Wright (ed.), International Encyclopedia of the Social \& Behavioral Sciences (2nd ed., Amsterdam, Elsevier, 2015), at $72-76$.

8 L Edwards, "Is China Totalitarian?" (The Heritage Foundation, 26 February 2020), https://perma.cc $/ \mathrm{TF}_{25}-\mathrm{SJ}_{5} 6$.

9 Human Rights Watch, "World Report 2020" (2O20), https://perma.cc/S79K-ZK7Y, at 4-5.

10 B Stephens, "China and the Rhineland Moment: America and Its Allies Must Not Simply Accept Beijing's Aggression” (New York Times, 29 May 2020), https://perma.cc/RR4Z-HXT5.

11 L Holmes, "Totalitarianism," in JD Wright (ed.), International Encyclopedia of the Social ङ Behavioral Sciences (2nd ed., Amsterdam, Elsevier, 2015), at 448-452. 
Whichever nation can foster the greatest "strategic knowledge competence" among the largest number of its citizens is likely to emerge as the leader of the global Knowledge Revolution. Whether it is more accurate to characterize China today as totalitarian or merely authoritarian, few China watchers appear convinced China will be able to overtake the West in the production of knowledge. In 1945, Frederick von Hayek contrasted the kind of formal, scientific knowledge that technocrats could centralize and control with the decentralized, unorganized kind of "knowledge of particular circumstances of time and place" that technocrats cannot easily control but that individuals actually use to solve the concrete problems they face. ${ }^{12}$ Societies controlled by unaccountable elites might be able to surpass more democratic societies in the production of technocratic knowledge, but more democratic societies seem more likely to produce more of the kind of practical knowledge Hayek believed would translate into greater market competitiveness. For example, firms in China with more than fifty employees are required to have a Chinese Communist Party (CCP) representative, while companies with more than a hundred employees are required to have a CCP cell. ${ }^{13}$ Individuals who know these representatives and cells are being used to monitor their words and conduct may curtail their efforts to produce "knowledge of particular circumstances" in order to reduce the risk they might suffer negative consequences for inadvertently violating some CCP norm. The use of highly pejorative terms such as totalitarian when less pejorative terms such as authoritarian might be more accurate suggests how deeply some of China's Western critics are discounting the possibility that China might prevail over the West by cultivating greater "strategic knowledge competence" among its citizens.

Some other China watchers in the West, however, have detected evidence that the number of Chinese citizens and enterprises developing knowledge as a strategic competence may be growing rapidly. Taiwan-born entrepreneur and research scientist Lee Kai-Fu has described the emergence in China of many unique and highly forms of disruptive innovation that are enjoying phenomenal success in China and around the world. ${ }^{14}$ For example, because digital entrepreneurs in China face the same threat of software piracy as foreign firms, they quickly learned that any competitive advantage gained on the basis of the kind of "pure play" Internet business model favored by Western technology entrepreneurs was unlikely to be sustainable. So they responded to local market conditions by developing the "online-to-offline" $\left(\mathrm{O}_{2} \mathrm{O}\right)$ business model in order to mitigate intellectual property piracy risks. The "O $\mathrm{O}_{2} \mathrm{O}$ Revolution" in China is made up of firms that invest in physical assets such as delivery vehicles and staff such as drivers to provide more than a digital experience to their users, which in turn creates barriers to market entry.

12 F von Hayek, "The Use of Knowledge in Society" (1945) 35 American Economic Review 519.

13 RM Abrami et al., "Why China Can't Innovate" (2014) 92 Harvard Business Review 107-111.

14 K-F Lee, AI Superpowers: China, Silicon Valley and the New World Order (Boston, MA, Houghton Mifflin Harcourt, 2018). 
Management consultant Edward Tse highlights the resilience of many Chinese entrepreneurs in a legal environment for business that provides them with considerably less predictability than their Western counterparts enjoy. ${ }^{15}$ Tse believes that China's domestic disruptors such as Alibaba, Tencent, Xiaomi, Haier and Huawei often triumph over their foreign rivals not because they are sheltered by protectionist government policies, but because they are better than their foreign rivals at accelerating decision-making, increasing flexibility and continually updating products and capabilities. Political scientist Douglas Fuller has identified a "global hybrid" model of innovation that outperforms purely foreign or purely domestic firms by combining overseas Chinese management talent and foreign financial capital with responsiveness to domestic government policy and global market conditions.

This chapter will consider how nations' pursuit of competitive advantage might unfold within the context of a global Knowledge Revolution, and how China might triumph in a contest among nations to foster the greatest "strategic knowledge competence" among the largest number of citizens. The victor in that contest would be well positioned to lead the design of the global knowledge infrastructure being produced by the "nexus of forces" of digital disruption. The competition between the USA and China to lead the design of the next great global knowledge infrastructure can be compared to the nineteenth-century "land rushes" the USA used to open land in the Oklahoma Territory to white settlement, and to the first great global knowledge economy "land rush" triggered by the commercialization of the Internet in the late 199os. The vulnerability of the current international trade law regime to disruption by China's efforts to disseminate its own legal and values culture through global networks and platforms is considered next, and placed within the context of China's distinctively pluralist legal culture. The chapter concludes that it may not be in the self-interest of Western nations to discount too heavily the possibility that China might ultimately prevail in its efforts to preempt the USA from the role of lead designer of the next great global information infrastructure.

\section{A KNOWLEDGE REVOLUTION MAY TRIGGER A GLOBAL INFORMATION} INFRASTRUCTURE LAND RUSH

All your base are belong to us. ${ }^{16}$

Between 1889 and 1895 in what later became the state of Oklahoma, the US General Land Office carried out seven "land rushes" to allocate land to white settlers. ${ }^{17}$ Settlers could claim lots of up to 160 acres of land and if they lived on the land and

15 E Tse, China's Disruptors: How Alibaba, Xiaomi, Tencent, and Other Companies Are Changing the Rules of Business (New York, Portfolio, 2015).

16 Internet meme derived from the English subtitle on the Zero Wing video arcade game produced in Japan in 1991. J Benner, "When Gamer Humor Attacks" (WIRED, 23 February 2001), https://perma.cc /6BZF-VTLE.

${ }_{17}$ See "The Encyclopedia of Oklahoma History and Culture," https://perma.cc/Q2 $\mathrm{HN}_{2} \mathrm{~A}_{5} \mathrm{PW}$. 
farmed it, they could acquire title to it after five years. For a variety of reasons, including endless litigation between "boomers" who claimed land after the official start of the land run and "sooners" who had snuck in before the official start, the process was never repeated in any other American territory following the settlement of Oklahoma. But the general idea of a "land rush" or "land run" remains seared into American cultural memory and provides an apt metaphor for the emerging superpower contest to lead the development of the next great global knowledge architecture.

The first great global knowledge infrastructure competition reminiscent of an Oklahoma land rush began in the early 1990 s as network engineers began to reject the International Organization for Standardization (ISO) Open Systems Interconnection (OSI) model for a comprehensive global information architecture in favor of the much simpler TCP/IP (transmission control protocol/internet protocol) standard that defines the Internet. ${ }^{18}$ The US Department of Defense's Advanced Research Projects Agency (ARPA) had begun testing designs for a "packet-switched" network (i.e., not "circuit-switched" like a telephone network) in 1969. In 1972, the "International Network Working Group" (INWG) was launched by European and American research scientists and network engineers with the mission of developing a global data networking standard to complement global telephone networking standards. The efforts of ARPA and INWG to develop a standard for computer networks proceeded collaboratively for a few years, but bifurcated around 1976 . European research scientists and network engineers then helped to launch a broad, collaborative, international effort that turned into the ISO OSI project, while the American research scientists and network engineers worked within ARPA and with support from the US Department of Defense. In 1983, the "Internet" was born when the US Department of Defense began requiring the use of the TCP/IP networking standard within the growing community of academic researchers and defense contractors it was funding. By the early 1990s, the OSI project got bogged down in the effort to build an international consensus in support of a comprehensive framework of standards while the more narrowly scoped TCP/IP project powered ahead with actual adoptions among a growing number of public and private sector users in the USA and around the world.

When the US National Science Foundation turned over maintenance of the "backbone" of the global data network defined by the TCP/IP standard to the private sector in 1995, its Acceptable Use Policy prohibiting commercial use of the Internet was officially terminated, and the global internet commerce "land rush" took off. Because American academics, businesses and government agencies already had a decade or more of experience working with the Internet on the day the Internet land rush started, they enjoyed an enormous competitive advantage over their

18 AL Russell, “OSI: The Internet That Wasn't" (IEEE Spectrum, 30 July 2013), https://perma.cc/V7EH$635 \mathrm{X}$. 
foreign counterparts in countries whose academics, businesses and government agencies had been working on the OSI standards.

Once it was obvious that the American solution would prevail over the multilateral solution developed under the aegis of international standards bodies such as the ISO and the International Telecommunications Union (ITU), other nations have repeatedly, but so far unsuccessfully, attempted to wrest control over the Internet from the USA. When other Western nations began threatening in the 199os to challenge US control of the Internet, the USA responded in 1998 by establishing the Internet Corporation of Assigned Names and Numbers (ICANN), a California nonprofit corporation, to act as a global, multistakeholder forum within which Internet governance issues could be resolved under the watchful eye of the USA. In 2003 and 2005, the United Nations organized the World Summit on the Information Society in an effort to address digital divide issues and promote inclusive global internet governance strategies. Many critics of the dominance of US interests in global internet governance demanded that authority over the Internet be turned over to the ITU to manage together with the global telephone system, a suggestion the USA flatly rejects whenever it is made. The US response to both summits was to reaffirm its commitment to letting the private sector lead the development of the global information architecture, to retain US control over the "root servers" that provide the foundation for the global domain name system, and to ignore criticism of its influence on governance matters. ${ }^{19}$ Because the Internet was not designed to accommodate censorship, countries that do not welcome the influence of American values in their societies - including in Bahrain, China, Iran, Russia, Saudi Arabia, Syria, Turkey and the United Arab Emirates - have been forced to construct and operate their own filtering systems to block their citizens' access to internet content they find objectionable. ${ }^{20}$

The Internet today remains a global network of networks that all make use of TCP/IP communications protocols for interoperability. Global support for the Internet notwithstanding, these controversies are due in part to the positive "network effects" consumers around the world enjoy from using it. A network may be defined as:

a set of actors or nodes along with a set of ties of a specified type (such as friendship) that link them. The ties interconnect through shared end points to form paths that indirectly link nodes that are not directly tied. ${ }^{21}$

A network effect is one example of a market "externality" (i.e., a cost or benefit not reflected in a product's price). A positive network effect arises when the value to

19 M Farrell, "How the Rest of the World Feels about U.S. Dominance of the Internet" (Slate, 18 November 2016), https://perma.cc/9CJ3-VWNB.

20 J Clark et al., "The Shifting Landscape of Global Internet Censorship" (2017) Berkman Klein Center for Internet \& Society Research Publication, https://perma.cc/B $389-87$ RV.

${ }_{21}$ DS Halgin and SP Borgatti, "On Network Theory" (2011) 22 Organization Science 1168, at 1169. 
a consumer of a network increases the more other consumers use the same network. The popularity of telephones, fax machines, personal computers and email is due in part to positive network effects. ${ }^{22}$ Price competition among producers of interoperable goods and services that make up a network may benefit consumers if a network is defined by open standards rather than closed proprietary solutions. ${ }^{23}$

Economists studying networks and network effects coined the terms "first mover advantage" and "increasing returns to scale" to describe the distinctive features of competition carried out in markets defined by interoperability standards compared to competition in markets for natural resources or for agricultural or industrial products. ${ }^{24}$ Because individuals are often not motivated to join new networks until enough other users have joined to create positive network effects, the promoter of a new network often faces a "chicken and egg" problem of how to attract new users before a critical mass of users can be enrolled. The so-called first mover advantage arises once a network has been successfully launched, making its users reluctant to migrate to a new network until it is certain that all other users will also migrate. Users of an existing network may find themselves "locked in" to that network if promoters of a new network cannot persuade enough users to leave the existing network. One way to diminish the risk of lock-in to a single proprietary network service provider is to define networks with "open" interoperability standards. This permits many competing firms to participate in the operation of a network simultaneously without fragmenting the network and diminishing the positive network effects users enjoy while at the same time securing for users the benefits of competition among network service providers.

If the operator of a successful network can also launch a "two-sided market" (also known as a "multisided market" or a "multisided platform") that runs on the network, this may amplify the market power of the operator. ${ }^{25}$ A simple model of a multisided platform is a two-sided market where the participation of two very different groups, each subject to very different terms and conditions, sustains the market. Traditional newspaper publishing is an example of a two-sided market with readers being one "side," advertisers being the second "side" and the newspaper publisher acting as the "platform operator." Traditional stock markets such as the New York Stock Exchange can also be thought of as a two-sided market, bringing together companies issuing securities and investors buying securities, with the issuers subsidizing access by investors. Multisided platforms may bring together three or more distinct groups: LinkedIn is a three-sided platform organizing different experiences for individuals, recruiters and advertisers, while Microsoft Windows

22 J Farrell and G Saloner, "Standardization, Compatibility, and Innovation" (1985) 16 RAND Journal of Economics 70.

23 ML Katz and C Shapiro, "Network Externalities, Competition, and Compatibility" (1985) 75 American Economic Review 424.

24 C Shapiro and H Varian, Information Rules (Boston, MA, Harvard Business School Press, 1999).

25 J-C Rochet and J Tirole, "Platform Competition in Two-Sided Markets" (2003) 1 Journal of the European Economic Association 990. 
operates as a three-sided platform for individuals, equipment manufacturers and third-party software developers. ${ }^{26}$ Google's Android mobile ecosystem has many different sides including users, telephone manufacturers, third-party app developers, network carriers and advertisers. ${ }^{27}$

Although two-sided, or multisided, markets exist apart from ICT networks, many of the most successful global information economy enterprises - such as Google, Apple, Facebook, Amazon, Microsoft, Netflix, Airbnb, Uber, Salesforce, eBay, Twitter, Alibaba, Tencent, Baidu and Xiaomi - operate as digital platforms. In order for a multisided market to operate successfully, the platform operator must devise a pricing strategy that maximizes the commitment of both sides to the success of the platform. Newspapers traditionally charged advertisers high prices for access to readers, and used those advertising revenues to subsidize readers. A successful platform pricing strategy normally imposes high prices on the side that is most committed to the success of the platform and uses low or subsidized prices to attract less committed users.

While one way to think about digital platforms is as private marketplaces, they can also be thought of as private regulators or governance systems. ${ }^{28}$ Just as territorial sovereigns can tax citizens either for the benefit of the sovereign personally or to defray the cost of providing public goods to citizens, successful digital platform operators may charge one or more groups of users prices fixed high above their production costs either to provide a return to their investors or to subsidize the cost of providing the platform as a public good to members of a different group. This ability of very successful platform operators to charge high prices to some groups of users for long periods of time, combined with the dearth of European digital platforms, has incited European competition regulators to target them for heightened scrutiny and enforcement efforts. ${ }^{29}$

Up to this point, the public-facing efforts of governments to project their authority into the global internet have tended to focus on publishing information for citizens, and providing access to government-to-citizen or government-to-business services rather than trying to establish a public sector multisided platform. However, the economic logic of positive network effects and the capacity of multisided platforms to operate as self-sustaining governance mechanisms could just as easily serve public sector goals as private sector goals. A few countries such as Singapore have begun to operate sophisticated portals for government services that integrate a wide range of public sector services into an accessible dashboard that might one day evolve into

26 A Hagiu, "Strategic Decisions for Multisided Platforms" MIT Sloan Management Review 55, no.2 (Winter 2014), https://perma.cc/RBC8-KNXR.

27 M Campbell-Kell et al., "Economic and Business Perspectives on Smartphones as Multi-sided Platforms" (2015) 39 Telecommunications Policy 717.

28 JK Winn, "The Secession of the Successful: The Rise of Amazon as Private Global Consumer Protection Regulator" (2016) 58 Arizona Law Review 193.

29 N Petit, "European Competition Policy in Digital: What's Next?" (Competition Policy International, 4 August 2019), https://perma.cc/ALS5-XL7B. 
a public sector multisided platform. The service today known as "National Trade Platform" (NTP) in Singapore was originally launched in 1989 with the goal of reducing barriers to cross-border trade. Singapore's NTP may be among the most mature and successful "platforms" for the delivery of government services in the world, but even the NTP has not yet publicly embraced the "multisided platform" model to expand its reach.

One of the few positive developments to emerge from the generally disappointing conclusion of the World Trade Organization (WTO) Doha Round of negotiations was the Trade Facilitation Agreement (TFA) in 2017. ${ }^{30}$ With the TFA, WTO members commit to "the simplification, modernization, and harmonization of export and import processes." ${ }^{31}$ Because the primary focus of the WTO TFA is on narrow operational issues such as the creation of national "single window" trade facilitation systems ${ }^{32}$ rather than broader economic issues, it might inadvertently serve to accelerate the creation of global digital trade facilitation platforms. The term "single window" in this context might best be understood as referring to a portal or channel through which communications between public and private sector parties might flow more easily. The Singapore NTP trade portal is a good example of such a single window system: it provides importers and exporters with a single point of contact with Singapore regulators.

Once enough national single window systems are up and running, the focus of WTO members will eventually turn to the kind of interoperability issues involved in transforming national systems into a multisided global digital trade facilitation platform. Some WTO members may be able to shift their focus to these interoperability issues before others. In 2019, the Asia Pacific Economic Cooperation (APEC) Committee on Trade and Investment (CTI) benchmarked the efforts of APEC members to adopt interoperable single window systems. ${ }^{33}$ The APEC CTI found that Association of Southeast Asian Nations (ASEAN) members and Pacific Alliance members had achieved the highest level of its "capability maturity model" and so could support cross-border interoperability.

Some private sector efforts to launch true multisided trade facilitation platforms have also begun to gain some traction. In 2017, Alibaba and other stakeholders in China partnered with the government of Malaysia to launch the Electronic World Trade Platform (eWTP), ${ }^{34}$ and by 2020, Belgium, Ethiopia, Rwanda and Thailand

30 "Global Trade after the Failure of the Doha Round" (New York Times, 1 January 2016), https://perma .cc/JAG7-G7 $\mathrm{C}_{4}$; Protocol Amending the Marrakesh Agreement Establishing the World Trade Organization, Decision of 27 November 2014, WT/L/940, adopted 28 November 2014; entered into force on 22 February 2017 following the ratification by two-thirds of the WTO membership.

${ }^{31}$ World Trade Organization, "World Trade Report 2015" (2015), https://perma.cc/CV54-DR4X, at 34.

32 WTO Trade Facilitation Agreement (TFA), art. 10.

33 APEC Committee on Trade and Investment, "Compendium of Best Practice Technology Solutions for Single Window Interoperability” (2019), https://perma.cc/EJ5D-A9NY.

34 B Jaipragas, "Free Trade for Minnows: How Alibaba Gave Malaysia's E-hub Hopes a Boost" (South China Morning Post, ${ }_{3}$ November 2017), https://perma.cc/63MH-2PJ4. 
as well as the Chinese cities of Hangzhou and Yi Wu were participants. ${ }^{35}$ In 2018, the Singapore information technology company vCargo Cloud announced the launch of its CamelONE trade facilitation platform. ${ }^{36}$ By 2020, the CamelONE trade facilitation platform was offering logistics and trade finance services through Singapore's NTP with the support of the Monetary Authority of Singapore.

It has not yet become clear which nation or region will be in the best position to seize the "first mover advantage" in the new global knowledge economy land rush triggered by disruptive "nexus of forces" innovations. The USA is unlikely to be deposed as chief architect of the global knowledge architecture merely by the kind of efforts undertaken so far by individual enterprises such as China's Alibaba or Singapore's vCargo Cloud, or regional associations of emerging economies such as ASEAN or the Pacific Alliance to promote the interoperability of national single window projects. By contrast, it is possible the USA could be deposed by a concerted effort by China. The remaining sections of this chapter will examine different factors likely to contribute to the leadership of the global knowledge economy remaining under Western control or coming under China's control.

III THE ROLE OF ARTIFICIAL INTELLIGENCE IN THE NEW LEGAL ORDER OF UNCERTAINTY IN WORLD TRADE LAW

In considering this question, then, we must never forget that it is a constitution we are expounding. ${ }^{37}$

The [European] Community constitutes a new legal order of international law for the benefit of which [European nations] have limited their sovereign rights. $3^{8}$

Historical experience has proven that failures in the economic sphere can result in major disorder, and failure in the ideological sphere can result in major disorders as well. ${ }^{39}$

As the trade war between the USA and China erupted in 2018, one pessimistic commentator announced the death of the WTO. ${ }^{4^{\circ}}$ By 2020 , the dire predicament of the WTO had become obvious to even casual observers. ${ }^{41}$ In 2018, President Trump announced he would block the appointment of judges to the WTO Appellate Body, and by 2020 it could no longer accept any new appeals because there were no longer

35 “Electronic World Trade Platform: Public Service Platform,” https://perma.cc/9CXW-CQCA.

${ }_{3} 6$ NS Wei, "Riding the Digital Silk Road" (Business Times Singapore, 13 March 2018), https://perma.cc 157 CS-FD7A.

37 McCulloch v. Maryland, 17 U.S. (4 Wheat.) 316 (1819).

$3^{8}$ Van Gend en Loos v Nederlandse Administratie der Belastingen (1963) Case 26/62.

39 九号文件: 关于当前意识形态领域的形势和主要任务 [Document No. 9 on the Current Situation and Main Tasks in the Field of Ideology (2013)].

$4^{\circ}$ E Alden, "Trump, China, and Steel Tariffs: The Day the WTO Died” (Council on Foreign Relations, 9 March 2018), https://perma.cc/XG $3 \mathrm{~N}_{-} \mathrm{Z}_{7} \mathrm{D}_{4}$.

${ }^{41}$ B Baschuk, "Who Will Lead the WTO and Help It Avoid Collapse?" (Bloomberg, 21 May 2020), https://perma.cc/9RCD-L64D. 
enough judges left to form new review panels..$^{42}$ As the WTO and the legal order it anchors are increasingly hobbled by the indifference or even hostility of some of the very world powers that were once its staunchest defenders, all participants in the world trade system now confront a new legal order of uncertainty. The emerging superpower contest between the USA and China to lead the development of the next great global knowledge architecture will likely be fought out within this terrain of legal uncertainty.

Although the WTO's many detractors do not all agree on what is wrong with it, some of its shortcomings are alleged to include the way intellectual property rights are currently handled, the unequal allocation of costs and benefits of trade liberalization within national economies, and the apparent ability of a few countries such as China to extract disproportionate benefits under the current regime. ${ }^{43}$ (The perception that China is uniquely positioned to exploit the current world trade system is, of course, relatively recent, given that Chinese accession in 2001 was conditioned on its agreement to exceptionally onerous concessions. ${ }^{44}$ ) While some manifestations of the emerging global knowledge economy - such as intellectual property rights or telecommunications - may clearly be governed by the international law regime governing trade, others - such as data flows or the market power of digital platforms - are not. After the Doha Round ended in stalemate and the USA withdrew from negotiations on regional trade agreements such as the Trans-Pacific Partnership Agreement, it is unclear how the WTO system can address any of the most serious criticisms leveled against it or respond to new challenges such as $\mathrm{AI}{ }^{45}$

One commentator has suggested that any new order of international trade law shaped by China's primacy in the global economy will likely retain many features of the old order:

But even if China's influence has grown, it has no desire to step into America's shoes and provide global leadership ... China regained its strength by plugging into the rules-based global order that America gifted to the world in 1945. China has no desire to overturn this order. It would be happy to cooperate with America within it. ${ }^{46}$

Given the enormity of the differences between law in China and in Western nations, as China's influence in shaping international trade law and legal institutions

42 A Swanson, "Trump Cripples W.T.O. as Trade War Rages" (New York Times, 8 December 2019), https://perma.cc/7 $\mathrm{VY}_{9}-\mathrm{Y}_{8} \mathrm{~V}_{3}$.

43 J McBride and A Chatzky, "What's Next for the WTO?" (Council on Foreign Relations Backgrounder, 10 December 2019), https://perma.cc/5BZB-M7UL.

44 Xiaohui Wu, "No Longer Outside, Not Yet Equal: Rethinking China's Membership in the World Trade Organization" (2011) 10 Chinese Journal of International Law 227-270.

45 A Goldfarb and D Trefler, "How Artificial Intelligence Impacts International Trade" (2018), https:// perma.cc/W6ZJ-QGUW.

$4^{6}$ K Mahbubani, “China: Threat or Opportunity?" (Noema Magazine, 15 June 2020), https://perma.cc I7XTU-NDTS. 
continues to increase, the result is nevertheless also likely to be increased legal uncertainty for Western nations.

Just as the current WTO regime has its strengths and weaknesses, an international trade law regime influenced by Chinese law and legal institutions would also have strengths and weaknesses, although the strengths of such a system might not be readily apparent to China's detractors. This is in part because China has explicitly committed to the pursuit of "rule by law" rather than the "rule of law" as that term is understood among practitioners of public international law. ${ }^{47}$ The policies and procedures of the CCP can be understood as a source of law in China somewhat like customary law, although much more authoritative. ${ }^{4}$ As constitutional law expert Xu Xianming explained in 2017, "The Communist Party is simultaneously in the law, under the law and above the law." 49 The government of China, including its formal legal institutions, cannot serve as the ultimate repository of political power because the CCP enjoys a special status somewhat like "first among equals."50 Within this hybrid "political-legal" order, the exercise of judicial power by the courts is protected from interference from other branches of government, social organizations or individuals, but not from the Party. ${ }^{51}$

Compliance with law, whether international or municipal, may be seen as a function of the severity of the consequences for noncompliance combined with the probability of those negative consequences being meted out. ${ }^{2}$ If China can succeed in projecting its regulatory culture into global arenas by influencing the design of the next great global knowledge architecture just as the USA did with the Internet, then distinctively Chinese mechanisms for monitoring compliance with law might come to assume a greater role in international trade law. Furthermore, China is in the midst of developing just such a distinctively Chinese framework for monitoring compliance with law: the China social credit system (CSCS).

Under the CSCS, PRC government agencies are permitted to share data on compliance by individuals, companies and social organizations with various laws and regulations, and can place the names of serious offenders and serial scofflaws on blacklists and subject them to various restrictions on their activities. The regulators

$47 \mathrm{KN} \mathrm{Ng}$, "Is China a Rule-by-Law Regime?" (2019) 67 Buffalo Law Review 793.

$4^{8} \quad$ P Chang, "Diversified Legal Sources of Property Rights and Rules on Their Application" (2014) 4 Chinese Journal of Law 114.

49 “徐显明, 我的理解是, 共产党既在法律之中, 也在法律之下, 还在法律之上 $[\mathrm{Xu}$ Xianming: My Understanding Is that the Communist Party Is Within, Below and Above the Law]" (China Digital Times, 16 April 2017), https://perma.cc/24Az-TCJW.

50 The idea of "first among equals" (or primus inter pares) was a term used in Rome to describe the exercise of power by designated individuals within a system where members of the patrician class shared political power. ME Davies and H Swain, Aspects of Roman History 82 BC-AD 14: A SourceBased Approach (London, Routledge, 2010), at 384.

${ }^{51}$ L Li, "Political-Legal Order and the Curious Double Character of China's Courts" (2018) 6 Asian Journal of Law \& Society 19.

52 GS Becker, "Crime and Punishment: An Economic Approach" (1968) 76 Journal of Political Economy 169 . 
using the CSCS to increase the effectiveness of their enforcement efforts include those dealing with taxation, the environment, transportation, food safety and foreign economic cooperation, as well as the execution of court judgments. ${ }^{53}$ While in 2018 some commentators were unable to detect a significant role for $\mathrm{AI}$ in the CSCS, ${ }^{4}$ subsequent commentators have concluded that $\mathrm{AI}$ already plays an important role in CSCS. ${ }^{55}$ Given the great success enjoyed by AI applications in credit evaluation in the West, ${ }^{56}$ and the centrality of AI generally in the Belt and Road Initiative (BRI) and China's domestic economic development programs, it seems safe to assume that the role of AI within the CSCS will increase in the future.

Coverage of the CSCS in Western media often exaggerates its technological sophistication and the degree to which its different elements are integrated, resulting in intense criticism of what is presumed to be its profoundly dystopian nature. ${ }^{57}$ What goes by the name CSCS is not a single, monolithic organization but rather a collection of different policies and pilot programs designed to increase the negative consequences of not complying with legal obligations or well-established social norms as well as the positive consequences of conscientious compliance with law and important social norms. ${ }^{8}$ Viewed from this perspective, the CSCS can be understood as a collection of government interventions designed to correct some of the "social traps" 59 that plague Chinese society today. Social traps in social domains are analogous to market failures in economic domains, and thus something that carefully targeted government intervention might remedy or at least neutralize.

China has already begun to extend the reach of the CSCS internationally within the BRI framework. ${ }^{6 \circ}$ If China succeeds in integrating AI into its legal institutions, whether through the expansion of the CSCS or otherwise, as well as in embedding its legal values in a global digital trade facilitation platform, Western nations may find the resulting new global order of international law not merely uncertain but alarming as well. Yet such an evolutionary development is consistent with Western notions of transnational law as contested, dynamic and provisional, continuously

53 https://perma.cc/NE45-SLWM.

54 Y-J Chen et al., "Rule of Trust': The Power and Perils of China's Social Credit Megaproject" (2018) 32 Columbia Journal of Asian Law 1.

55 S Feldstein, "The Global Expansion of AI Surveillance" (2019) Carnegie Endowment for World Peace Working Paper, https://perma.cc/5GE5-C57M; S Hoffman, "Engineering Global Consent: The Chinese Communist Party's Data-Driven Power Expansion" (2019) Australian Strategic Policy Institute, Policy Brief Report No. 21, https://perma.cc/8FA3-3UR6.

56 "Explainable AI and the FICO Score" (FICO, 14 November 2018), https://perma.cc/G65N-HFED.

57 See P Dockrill, "China's Chilling 'Social Credit System' Is Straight Out of Dystopian Sci-Fi, and It's Already Switched On” (Science Alert, 20 September 2018), https://perma.cc/QFZ9-5V4U.

$5^{8}$ X Dai, "Enforcing Law and Norms for Good Citizens: One View of China’s Social Credit System Project" (2020) 63 Development 38.

59 J Platt, "Social Traps" (1973) 28 American Psychologist 641.

60 “一带一路”国际合作城市信用联盟成立 [‘Belt \& Road’ International Cooperative City Credit Alliance Established]" (Xinhua, 10 October 2020), https://perma.cc/7M8S-M3Y8. 
emerging partially formed from incomplete resolutions to conflicts arising within and across different legal domains. ${ }^{61}$

Sociologists use the term "institutional isomorphism" to describe a process whereby different organizations come to resemble each other, and recognize coercive, normative or mimetic variations. ${ }^{62}$ Coercive isomorphism compels conformity while normative isomorphism involves the dissemination of rules through the work of professionals. Mimetic isomorphism is produced by the voluntary copying of features of an institution that are perceived as beneficial. While China's detractors may believe that Chinese legal institutions and values could never prevail over their Western counterparts except through coercion, normative and mimetic isomorphism may also contribute to reshaping international trade law into something closer to China's idea of law. The work of global standard-setting organizations might contribute to the kind of normative and mimetic isomorphism that could expand the influence of Chinese legal values in international trade arenas. It should come as no surprise therefore that China has recently announced its intention to lead the development of global standards for disruptive "nexus of forces" innovations, including AI. ${ }^{63}$

Legal anthropologists have long recognized that treating law as a distinct and separate sphere apart from other human experience cannot produce an accurate account of legal processes. Legal anthropologists may begin their analysis by noting that legal institutions operate on multiple levels simultaneously and that a plurality of legal institutions interact with social structures outside the law in many different ways. ${ }^{6}$ These overlapping domains can be referred to individually as "semiautonomous social fields" ${ }^{65}$ or collectively as "legal pluralism." 66 As Sally Falk Moore explained:

Though the formal legal institutions may enjoy a near monopoly on the legitimate use of force, they cannot be said to have a monopoly of any kind on the other various forms of effective coercion or effective inducement. It is well established that between the body politic and the individual, there are interposed various smaller organized social fields to which the individual "belongs." These social fields have their own customs and rules and the means of coercing or inducing compliance. They have what Weber called a "legal order." 67

61 G Shaffer, "Theorizing Transnational Legal Ordering” (2016) 12 Annual Review of Law ङ Social Science 231.

62 PJ Dimaggio and WW Powell, “The Iron Cage Revisited: Institutional Isomorphism and Collective Rationality in Organizational Fields” (1983) 48 American Sociological Review 147.

63 N Wilson, "China Standards 2035 and the Plan for World Domination - Don't Believe China's Hype" (Council on Foreign Relations, 3 June 2020), https://perma.cc/ $\mathrm{H}_{74} \mathrm{~S}-\mathrm{HF}_{2} \mathrm{~N}$.

64 L Pospisil, "Legal Levels and Multiplicity of Legal Systems in Human Societies" (1967) 11 Journal of Conflict Resolution 2.

65 SF Moore, "Law and Social Change: The Semi-Autonomous Social Field as an Appropriate Subject of Study” (1973) 7 Law \& Society Review 719.

66 J Griffiths, "Legal Pluralism," in N Smelser (ed.), International Encyclopedia of the Social ๒ Behavioral Sciences (Amsterdam, Elsevier, 2001).

67 Moore, note 65 above, at 721. 
China's legal system manifests many characteristics of legal pluralism. For example, in 2016, the CCP issued a "Guiding Opinion" declaring that all laws, regulations and public policies should be implemented in a manner that supported appropriate social values, and in 2018 it announced a plan to insure that the core values of socialism are fully incorporated into law. ${ }^{68}$ By blurring the boundary between law, politics and morality, China is turning away from the modern notion of morality as a negative domain of unconstrained individual choice and turning toward mobilizing plural sources of law to promote conformity to specific ideas about individual morality. Even if this pluralist model of law is not appealing to China's critics in the West, it may be appealing to many of the nations in the Global South who wish to emulate China's economic miracle and do not consider the Western notion of the rule of law a feasible goal for them to pursue.

While those Western knowledge workers most likely to find their working conditions transformed by the rapid expansion of AI are quick to decry the dangers it poses, more level-headed observers consider its potential social benefits together with its potential social costs. ${ }^{6}$ The intransigence with which many lawyers in Western nations have resisted dimensions of digital transformation accepted as routine or even necessary by other citizens of Western nations is noteworthy in this regard, and may reveal more about the epistemic culture of the legal profession in the West than the likely impact of AI on human labor. ${ }^{70}$ Given their resistance to using lesser forms of automation of knowledge work, it should come as no surprise that Western trained lawyers are strenuously resisting any move away from bespoke production and distribution of legal services. ${ }^{71}$ By contrast, given China's interest in transcending Western notions of the rule of law, it should come as no surprise that China is embracing the automation of legal services more enthusiastically than Western nations. ${ }^{72}$ If China advances more quickly than the West in finding ways to automate the delivery of legal services, then the systems it develops might incorporate legal pluralist notions more fully than their Western analogs as a result of normative and mimetic isomorphism.

Leaders of nations in the Global South that have not yet embraced the modern Western ideal of rule of law might find attractive an international trade law regime that is both more compatible with their own pluralist legal systems and provides them increased access to global markets by means of a global digital trade facilitation platform. According to the World Bank, China has lifted 850 million of its citizens

68 D Lin and S Trevaskes, "Creating a Virtuous Leviathan: The Party, Law, and Socialist Core Values" (2019) 6 Asian Joumal of Law and Society 41, at 42.

69 A Howard and J Borenstein, "The Ugly Truth about Ourselves and Our Robot Creations: The Problem of Bias and Social Inequity" (2018) 24 Science \& Engineering Ethics 1521.

$7^{\circ} \mathrm{C}$ Brooks et al., "Artificial Intelligence in the Legal Sector: Pressures and Challenges of Transformation" (2020) ${ }_{13}$ Cambridge Journal of Regions, Economy and Society 135.

${ }_{71}$ R Susskind and D Susskind, The Future of Professions (Oxford, Oxford University Press, 2016), at 30.

72 Sarah Dai, "Shanghai Judicial Courts Start to Replace Clerks with AI Assistants" (South China Morning Post, 1 April 2020), https://perma.cc/A8NV-BQWJ. 
out of absolute poverty since Reform and Opening began in 1978. ${ }^{73}$ In 2016, in response to the question "Overall, are you satisfied or dissatisfied with the way things are going in our country today?" asked in a survey that the US Pew Research Group carries out annually in China, 86 percent of respondents reported being satisfied. ${ }^{74}$ If the nations of the Global South are offered the choice of participating in the conventional Western international trade law regime and a new Sinocentric international trade law regime based on legal pluralism and they conclude they face less risk of regime instability within the Chinese alternative, they might well find the Sinocentric alternative more appealing. If China can draw enough emerging economies into its sphere of influence through its BRI investments, access to CSCS surveillance technologies and more accommodating culture of legal pluralism, that might be enough to tip the balance in China's favor in the competition to lead the design of the next great global information infrastructure.

\section{CONCLUSION: WHOEVER RULES THE GLOBAL KNOWLEDGE INFRASTRUCTURE RULES THE WORLD?}

Whoever rules the waves, rules the world. ${ }^{75}$

As American baseball player, manager and cultural icon Yogi Berra observed, "It's tough to make predictions, especially about the future." With the next great global knowledge economy land rush just beginning, one of the few conclusions that can safely be drawn is that many Western observers appear to be discounting too severely the possibility of China's ultimate success. If the ambition of China's leaders to regain what they perceive as China's rightful place at the vanguard of human civilization $^{76}$ can be realized more quickly by harnessing the Knowledge Revolution, then in light of the pragmatism China's leaders have repeatedly shown since 1978, it is possible that China's leaders will find a way to overcome any anxieties they may feel about AI and push forward. If China expands the scope of its CSCS initiative to its BRI partners in the Global South, and decides to pursue a first mover advantage by launching the first successful global digital trade facilitation platform, then its investments in $\mathrm{AI}$ would serve to reinforce its rise to superpower status.

Just as one of the principal foundations of the British Empire was Britain's naval power, China may find a way to use superiority in $\mathrm{AI}$ as a foundation for its ascent to

73 World Bank, "China: Overview," https://perma.cc/6YPD-HG6U.

74 R Wike and B Stokes, "Chinese Public Sees More Powerful Role in World, Names U.S. as Top Threat" (Pew Research Center, 5 October 2016), https://perma.cc/J4KF-AK8C (since 2002, the percentage of Chinese reporting to the Pew Research Group they were satisfied has ranged from a low of 48 percent to a high of 91 percent).

75 AT Mahan, The Influence of Sea Power Upon History: 1660-1783 (Upper Saddle River, NJ, Prentice Hall, 1980).

76 M Schuman, Superpower Interrupted: The Chinese History of the World (New York, PublicAffairs, 2020). 
superpower primacy in the global economy. In 1960, J. C. R. Licklider foresaw the rise of human-computer symbiosis and suggested it should consist of humans setting the goals of technological innovation while machines carry out routine processes. ${ }^{77}$ If implementations of $\mathrm{AI}$ focus on complementing human labor rather than replacing it and the result is increased productivity, rising earnings and greater demand for labor ${ }^{78}$ then the ability to secure a global competitive advantage in AI might help to decide which superpower emerges victorious from the current contest between the USA and China. And then it could be said that whoever governs the global knowledge infrastructure governs the global economy.

77 JCR Licklider, "Man-Computer Symbiosis" (1960), https://perma.cc/P4Y3-NQAA.

$7^{8}$ DH Autor, "Why Are There Still So Many Jobs? The History and Future of Workplace Automation" (2015) 29 Journal of Economic Perspectives 3. 